\title{
PENGEMBANGAN PERANGKAT TES BAHASA ARAB BERBASIS KOMPETENSI UNTUK MADRASAH ALIYAH
}

\author{
Yelfi Dewi. S \\ Program Studi Pendidikan Bahasa Arab, Jurusan Tarbiyah STAIN Batusangkar \\ Korespondensi: Perumahan Permata Rizano Blok F/12 Cubadak, Batusangkar \\ e-mail: dewi.yelfi@yahoo.com
}

\begin{abstract}
The aim of this research was to create Arabic test tool based on valid basic competency, practical and effective for Islamic Senior High School. The method of this research was research development. This research had three stages; frontend analysis, prototype, and assessment. Front-end analysis result showed that it was needed an Arabic test tool as guidance to know the achievement of the teaching and learning objective. The Arabic test tool was designed based on the basic compentency. Then, the Arabic test tool was validated to the expert/ reviewer. The result of the research showed that: 1) Arabic test tool that was designed was already valid (content and construct validity) based on the expert and/or reviewer point of view; 2) The use of the Arabic test tool in teaching and learning process did not face any problems according to the students and teachers related to its practice; and 3) The Arabic test tool was already effective that can be seen from students' opinion after getting test and their good mark.
\end{abstract}

Kata kunci: bahasa Arab, pengembangan, perangkat tes, kompetensi.

\section{PENDAHULUAN}

$\mathrm{P}$

enelitian ini dilatarbelakangi oleh masih terdapat butir-butir soal yang ada dalam tes pilihan ganda, belum mewakili semua unsur dan kompetensi yang ada. Pada umumnya belum ada soal-soal yang mewakili pada aspek kemahiran mendengar (istima') dan bericara (kalam). Sedangkan sesuai dengan kurikulum yang dipakai yaitu kurikulum 2008 yang sesuai dengan Permenag RI No. 2 Th. 2008. Dalam kurikulum ini dituangkan Standar Kompetensi dan Kompetensi Dasar bahasa Arab berdasarkan pada aspek-aspek kemahiran dalam berbahasa yaitu mulai dari menyimak (istima'), berbicara (kalam), membaca (qira'ah) dan menulis (kitabah). Hal ini merupakan hasil analisis awal peneliti terhadap perangkat tes bahasa Arab pada dua tahun terakhir dan reviu kurikulum.

Para guru/ penulis soal harus mampu menyusun dan meningkatkan kemampuannya dalam penyusunan butirbutir tes yang bermutu (shahih, reliable, handal dan praktis) karena masih ada tes atau soal yang belum sesuai dengan ketentuan yang seharusnya. Ini perlu mendapatkan perhatian serius karena tes merupakan suatu cara untuk mengungkap ketercapaian tujuan atau kompetensi pembelajaran. Tes kebahasaan hendaknya memberi kesempatan kepada siswa untuk dapat menunjukkan kemampuanya dalam berbahasa, karena yang dimaksudkan adalah mengukur hasil belajar siswa.

Adapun komponen atau unsur kebahasaan yang diteskan meliputi hal- 
hal yang menjadi cakupan pengajaran bahasa yaitu unsur kebahasaan dan keterampilan berbahasa. Semuanya harus terdapat dalam butir-butir soal. Artinya butir-butir soal yang dibuat harus mencerminkan dan mewakili unsurunsur tersebut secara seimbang jangan sampai ada suatu unsur dan bagianbagiannya terlupakan. Begitu juga harus ada kesesuaian dan keterwakilan dari tujuan atau kompetensi yang tercantum dalam kurikulum. Evaluasi pembelajaran mempunyai prinsip-prinsip (M. Ainin, 2006: 12-16) yaitu, menyeluruh, berorientasi pada tujuan, objektif, terbuka, bermakna, sesuai, dan mendidik. Dalam konteks pembelajaran bahasa, prinsip menyeluruh mempunyai arti bahwa evaluasi dilaksanakan terhadap semua aspek kebahasaan yaitu kosa kata, struktur, ejaan, dan unsur-unsur prosodi. Evaluasi juga menyangkut seluruh bidang keterampilan berbahasa, baik reseptif maupun produktif. Lebih dari itu, evaluasi dilakukan terhadap semua ranah kemampuan, yaitu kognitif, psikomotor, dan afektif.

Berdasarkan latar belakang permasalahan tersebut, maka melalui penelitian ini dikembangkan perangkat tes bahasa Arab berbasis kompetensi. Penelitian ini diharapkan dapat menghasilkan perangkat tes bahasa Arab berbasis kompetensi yang valid, praktikal dan efektif. Perangkat tes yang dimaksud disini meliputi materi soal, konstruksi soal, dan bahasa yang digunakan.

\section{METODE PENELITIAN}

Penelitian ini dilaksanakan dengan menggunakan pendekatan penelitian pengembangan (development research). Pendekatan ini digunakan untuk merancang dan mengembangkan perangkat tes bahasa Arab berbasis kompetensi yang valid, praktikal dan efektif untuk Madrasah Aliyah. Kegiatan penelitian meliputi 3 tahap, yaitu: Analisis muka- belakang (Front-end analysis), Tahap Prototipe (Prototype), Tahap Penilaian (Assessment).

Kegiatan penelitian diawali dengan melakukan analisis muka-belakang (front-end analysis), meliputi: menganalisis perangkat tes yang digunakan di Madrasah Aliyah, mereviu literatur tentang pembuatan perangkat tes bahasa Arab, interviu dengan guru bidang studi bahasa Arab. Berdasarkan hasil tersebut, dirancang prototipe perangkat tes bahasa Arab.

Pembuatan prototipe dilaksanakan melalui 2 tahap yaitu tahap validasi dan praktikalitas. Kegiatan dimulai dengan proses siklis analisis pendahuluan dan penilaian pakar (expert review). Proses validasi disertai dengan diskusi atau wawancara langsung dengan pakar mengenai perbaikan yang harus dilakukan pada prototipe yaitu dengan cara rancangan perangkat tes bahasa Arab dikonsultasikan terlebih dahulu kepada pakar atau ahlinya, kemudian rancangan tersebut dinilai oleh orang-orang yang berkompeten (validator) yang telah memahami prinsip pengembangan, yaitu teman sejawat para dosen bahasa Arab. Validasi perangkat tes ini ada 2 macam pertama, Validasi isi yaitu apakah perangkat tes yang telah dirancang sesuai dengan pemilihan kompetensi materi uji. Kedua, Validitas Konstruk yaitu Kesesuaian komponen-komponen tes dengan unsur-unsur pengembangan yang sudah ditetapkan.

Praktikalitas adalah tingkat keterpakaian prototipe perangkat tes oleh guru dan siswa, yaitu dengan melaksanakan eksperimen evaluasi dengan menggunakan prototipe yang telah direvisi berdasarkan penilaian oleh validator atau yang merupakan hasil pada tahap pertama. Perangkat tes diujikan pada 3 orang siswa (uji coba kelompok kecil) dengan tingkat kemampuan rendah, sedang, dan tinggi. Perangkat tes dikatakan memiliki praktikalitas yang tinggi apa- 
bila bersifat praktis. Dalam arti mudah digunakan, mudah pemeriksaannya serta lengkap dengan petunjuk yang jelas.

Pada tahap penilaian (Assesment), kegiatan dipusatkan untuk mengevaluasi apakah prototipe (versi ujicoba) dapat digunakan sesuai dengan harapan dan efektif. Aspek efektifitas penggunaan perangkat tes diketahui dari kesan/ pendapat siswa setelah mengikuti tes dan hasil tes. Kesan siswa dapat diperoleh melalui wawancara yang dilakukan secara tertulis. Berikut ini dikemukakan indikator dari tahap-tahap penelitian dan aspek-aspek yang akan diselidiki beserta metode dan instrumen pengumpulan data.

Metode dan Instrumen Pengumpulan Data untuk Setiap Tahap Penelitian

\begin{tabular}{|c|c|c|c|c|}
\hline $\begin{array}{c}\text { Tahap } \\
\text { Penelitian }\end{array}$ & $\begin{array}{l}\text { Objek yang } \\
\text { dievaluasi }\end{array}$ & $\begin{array}{c}\text { Metode } \\
\text { Pengumpulan } \\
\text { data } \\
\end{array}$ & Instrumen & Subjek \\
\hline $\begin{array}{l}\text { Pembuatan } \\
\text { Prototipe }\end{array}$ & $\begin{array}{l}\text { Analisis kebutuhan } \\
\text { untuk menetapkan } \\
\text { materi tes }\end{array}$ & $\begin{array}{l}\text { Analisis dokumen, } \\
\text { Analisis literatur } \\
\text { dan interviu } \\
\text { dengan guru } \\
\text { bahasa Arab }\end{array}$ & $\begin{array}{l}\text { Catatan } \\
\text { lapangan }\end{array}$ & $\begin{array}{l}\text { Dokumen perangkat } \\
\text { tes bahasa Arab } \\
\text { Madrasah Aliyah } 2 \\
\text { tahun terakhir, } \\
\text { bahan ajar bahasa } \\
\text { Arab }\end{array}$ \\
\hline \multirow[b]{2}{*}{$\begin{array}{l}\text { Validitas } \\
\text { Perangkat }\end{array}$} & $\begin{array}{l}\text { Organisasi perangkat } \\
\text { tes, } \\
\text { Format penulisan, } \\
\text { Bahasa, dan ilustrasi }\end{array}$ & $\begin{array}{l}\text { Pemberian } \\
\text { kuisioner dan } \\
\text { lembar validasi } \\
\text { akhir (ceklis) }\end{array}$ & $\begin{array}{l}\text { Kuisioner dan } \\
\text { lembar cheklis }\end{array}$ & $\begin{array}{l}\text { Pakar Rancangan } \\
\text { (evaluasi } \\
\text { pendidikan) }\end{array}$ \\
\hline & $\begin{array}{l}\text { Organisasi perangkat } \\
\text { tes, format penulisan, } \\
\text { aspek penjabaran } \\
\text { materi bahasa, dan } \\
\text { ilustrasi }\end{array}$ & $\begin{array}{l}\text { Pemberian } \\
\text { kuisioner dan } \\
\text { lembar validasi } \\
\text { akhir (ceklis) }\end{array}$ & $\begin{array}{l}\text { Kuisioner dan } \\
\text { lembar cheklis }\end{array}$ & $\begin{array}{l}\text { Pakar Isi (bahasa } \\
\text { Arab) }\end{array}$ \\
\hline Praktikalitas & $\begin{array}{l}\text { Tentang kegunaan, } \\
\text { kemudahan terhadap } \\
\text { perangkat tes dan } \\
\text { kesan setelah } \\
\text { mengikuti proses } \\
\text { evaluasi }\end{array}$ & $\begin{array}{l}\text { - Pemberian tes } \\
\text { pada siswa } \\
\text { - Interviu dengan } \\
\text { guru dan siswa }\end{array}$ & $\begin{array}{l}\text { - Lembar } \\
\text { jawaban tes } \\
\text { - Pedoman } \\
\text { Wawancara } \\
\text { (guru dan } \\
\text { siswa) }\end{array}$ & $\begin{array}{l}3 \text { orang siswa } \\
\text { (kemampuan } \\
\text { beragam)/uji } \\
\text { coba kelompok } \\
\text { kecil, } 2 \text { orang guru } \\
\text { bahasa Arab }\end{array}$ \\
\hline Efektifitas & $\begin{array}{l}\text { Hasil tes bahasa } \\
\text { Arab, kesan setelah } \\
\text { mengikuti proses } \\
\text { evaluasi }\end{array}$ & $\begin{array}{l}\text { Pemberian Tes } \\
\text { dan interviu }\end{array}$ & $\begin{array}{l}\text { Lembar } \\
\text { jawaban tes, } \\
\text { pedoman } \\
\text { wawancara }\end{array}$ & 1 lokal Siswa \\
\hline
\end{tabular}

\section{HASIL PENELITIAN}

Perangkat tes bahasa Arab dirancang berdasarkan analisis muka belakang. Kegiatan ini dimulai dari analisis perangkat tes yang digunakan di Madrasah Aliyah, mereviu literatur tentang pembuatan perangkat tes bahasa Arab, interviu dengan guru bidang studi bahasa Arab.

Analisis perangkat tes dilakukan berdasarkan kurikulum bahasa Arab untuk Madrasah Aliyah yaitu kurikulum PERMENAG tahun 2008. Prinsip yang diacu dalam menetapkan perangkat tes bahasa Arab ini adalah bahwa tes bahasa Arab dilakukan untuk melihat 
ketercapaian unsur-unsur yang terdapat dalam kurikulum, dalam hal ini silabus bahasa Arab. Sebagaimana layaknya tujuan diadakannya tes yaitu untuk mengetahui ketercapaian siswa terhadap tujuan pembelajaran yang sudah dirumuskan dalam kurikulum. Oleh sebab itu perangkat tes seharusnya dapat memberikan informasi terhadap kemampuan siswa dalam bahasa Arab yang terlihat dari pencapaian keterampilan berbahasa siswa mulai dari keterampilan mendengar (istima'), berbicara (kalam), membaca (qira'ah), dan menulis (kitabah).

Berdasarkan hal ini, maka peneliti menetapkan perangkat tes yang akan dikembangkan. Perangkat tes yang dimaksud adalah: butir-butir soal disajikan sesuai dengan urutan pencapaian keterampilan berbahasa sebagaimana terdapat dalam kurikulum yaitu mulai dari soal untuk menguji keterampilan mendengar (istima'), kemudian kalam, qira'ah, dan terakhir kitabah. Berikut ini diuraikan materi-materi pengembangan perangkat tes pada tabel dibawah ini:

Materi-materi Pengembangan Perangkat Tes Bahasa Arab

\begin{tabular}{|c|c|c|c|c|}
\hline Tes & Kemahiran & Perintah Soal & Nomor Soal & $\begin{array}{l}\text { Jml } \\
\text { Soal }\end{array}$ \\
\hline \multirow{4}{*}{1} & \multirow{4}{*}{ Istima’ } & في القراءة! الجملة الآتية و عين المفردات الصحيحة كما & 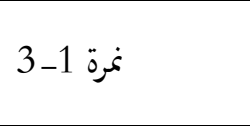 & 3 \\
\hline & & استمع الحوار ثم اجب عن الأسئلة الآتية! & 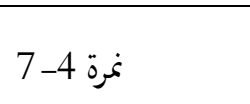 & 4 \\
\hline & & استمع من القطعة الآتية واكمل & & \\
\hline & & الجمل الآتية! & 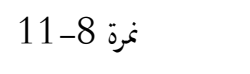 & 4 \\
\hline \multirow{3}{*}{2} & \multirow{3}{*}{ Kalam } & 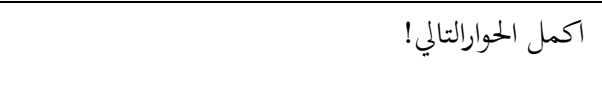 & 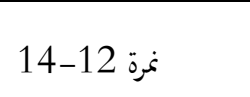 & 3 \\
\hline & & اجب عن الأسئلة الآتية حسب الحوار التالى! & 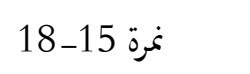 & 4 \\
\hline & & 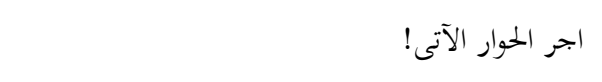 & 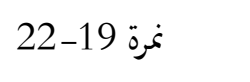 & 4 \\
\hline \multirow{5}{*}{3} & \multirow{5}{*}{ Qira'ah } & اضبط الكلمة التى تحته ا خط بشكل صحيح! & 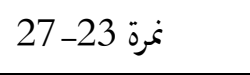 & 5 \\
\hline & & ترجمم الكلمة التى تحتها خط إلى اللغة الإندونسية & 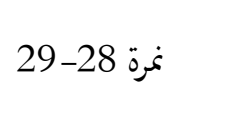 & 2 \\
\hline & & اقرأ الناص الآتى و عين الموضوع المناسب! & 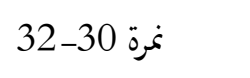 & 3 \\
\hline & & ترجم الجمل الآتية إلى اللغة الإندونسية الجيدة! & 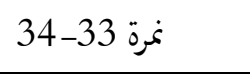 & 2 \\
\hline & & عين المقصود من الكلمات التى تحتها خط! & 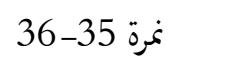 & 2 \\
\hline
\end{tabular}




\begin{tabular}{|c|c|c|c|}
\hline \multirow{5}{*}{4} & \multirow{5}{*}{ Kitabah } & عين الكتابة الصحيحة من الكلمة الآتية! & 2 \\
\hline & & صحيحة! الكلمات التى تحتها خط كتبت خطأ فاختر كتابة & 2 \\
\hline & & رتب الكلمات الآتية لتكون جملا مفيدة! & 3 \\
\hline & & ترجم الجملة الآتية إلى اللغة العربية الفصيحة! & 2 \\
\hline & & نمرة 46 صل الجملتين لتكون جملة مفيدز & 1 \\
\hline \multirow{3}{*}{5} & \multirow{3}{*}{ Struktur Bahasa } & نمرة 47 حول الفعل المضارع حسب الض & 1 \\
\hline & & نغرة 48_49 الضمير من الفعل الآتى! & 2 \\
\hline & & نمرة50 اعرب الكلمة التى تحتها خط ! & 1 \\
\hline \multicolumn{2}{|c|}{$\begin{array}{l}\text { Karakteristik perangkat tes yang di- } \\
\text { kembangkan oleh peneliti adalah ber- } \\
\text { dasarkan kerangka materi diatas. Karak- } \\
\text { teristik perangkat tes /butir-butir soal } \\
\text { yang dimaksud adalah: } \\
\text { a. Perangkat tes yang dikembangkan } \\
\text { disajikan dengan disain gambar me- } \\
\text { narik pada butir-butir soal untuk } \\
\text { membantu siswa agar mudah dan } \\
\text { cepat mengingat makna kata yang } \\
\text { terdapat pada butir-butir soal. } \\
\text { b. Perangkat tes disusun berdasarkan } \\
\text { analisis kebutuhan siswa Madrasah } \\
\text { Aliyah dalam memahami materi tes } \\
\text { bahasa Arab. } \\
\text { c. Setiap butir soal disusun berdasarkan } \\
\text { urutan kompetensi yang terdapat da- }\end{array}$} & $\begin{array}{l}\text { lam silabus kurikulum } \\
2008 \text {. } \\
\text { d. Butir-butir soal disusur } \\
\text { kat kesukaran yang b } \\
\text { tingkat kesukaran re } \\
\text { tingkat tinggi. } \\
\text { e. Bahasa dan isi materi } \\
\text { suai dengan tingkat ke } \\
\text { wa Madrasah Aliyah ya } \\
\text { Perangkat tes baha } \\
\text { telah dirancang, selanjut } \\
\text { tasikan kepada dua oran } \\
\text { pakar rancangan dan isi } \\
\text { saran validator rancan } \\
\text { beberapa bagian dari disair } \\
\text { yang harus diperbaiki. R } \\
\text { sarankan oleh validator se } \\
\text { dapat dilihat pada tabel ber }\end{array}$ & $\begin{array}{l}\text { IENAG } \\
\text { an ting- } \\
\text { ng dari } \\
\text { hingga } \\
\text { ouat se- } \\
\text { dan sis- } \\
\text { rogen. } \\
\text { b yang } \\
\text { konsul- } \\
\text { rr yaitu } \\
\text { asarkan } \\
\text { terdapat } \\
\text { gkat tes } \\
\text { ang di- } \\
\text { rperinci }\end{array}$ \\
\hline
\end{tabular}


Daftar Revisi dari Validator Rancangan

\begin{tabular}{|c|c|c|c|}
\hline $\begin{array}{l}\text { Aspek yang } \\
\text { divalidasi }\end{array}$ & Komentar & Saran & $\begin{array}{l}\text { Tindak } \\
\text { lanjut }\end{array}$ \\
\hline $\begin{array}{l}\text { Pendahuluan } \\
\text { perangkat tes }\end{array}$ & $\begin{array}{l}\text { Judul belum ada, mata } \\
\text { pelajaran tidak ada, alokasi } \\
\text { waktu belum ada, } \\
\text { Petunjuk soal belum } \\
\text { lengkap }\end{array}$ & $\begin{array}{l}\text { - Judul sebagai kepala } \\
\text { halaman dibuat dengan kata- } \\
\text { kata " LEMBARAN } \\
\text { SOAL" } \\
\text { - Nama mata pelajaran yaitu } \\
\text { bahasa Arab, dicantumkan } \\
\text { sejajar dengan alokasi waktu } \\
\text { - Petunjuk soal dibuat menjadi } \\
\text { dua yaitu petunjuk umum } \\
\text { dan khusus. }\end{array}$ & $\begin{array}{l}\text { Pendahuluan } \\
\text { perangkat } \\
\text { tes dibuat } \\
\text { dan } \\
\text { dilengkapi. }\end{array}$ \\
\hline $\begin{array}{l}\text { Karakter } \\
\text { Pengetikan }\end{array}$ & $\begin{array}{l}\text { - Ukuran besar huruf } \\
\text { belum dapat menarik } \\
\text { perhatian pembaca } \\
\text { - Tulisan terkesan padat } \\
\text { dan rapat }\end{array}$ & $\begin{array}{l}\text { - nomor halaman dicantumkan } \\
\text { dipojok kanan atas } \\
\text { - Penataan paragraf } \\
\text { penomoran sebaiknya rata } \\
\text { kanan } \\
\text { - Sebaiknya font dan karakter } \\
\text { huruf dalam pengetikan } \\
\text { diganti }\end{array}$ & Dilakukan \\
\hline Susunan soal & $\begin{array}{l}\text { - Soal sudah disusun } \\
\text { berdasarkan urutan } \\
\text { kompetensi yang } \\
\text { terdapat dalam silabus } \\
\text { kurikulum PERMENAG } \\
2008 \text {. } \\
\text { - Butir-butir soal sudah } \\
\text { disusun dengan tingkat } \\
\text { kesukaran yang } \\
\text { berjenjang dari tingkat } \\
\text { kesukaran rendah hingga } \\
\text { tingkat tinggi }\end{array}$ & - & - \\
\hline $\begin{array}{l}\text { Penyajian } \\
\text { gambar }\end{array}$ & $\begin{array}{l}\text { Disain gambar sudah ada, } \\
\text { tapi ada yang kurang jelas }\end{array}$ & $\begin{array}{l}\text { - Gambar harus jelas supaya } \\
\text { maksud tercapai } \\
\text { - Upayakan disajikan gambar } \\
\text { bewarna }\end{array}$ & Direvisi \\
\hline
\end{tabular}

Berdasarkan uji coba perseorangan kepada pakar Isi terdapat beberapa bagian dari isi perangkat tes yang harus diperbaiki. Revisi yang disarankan oleh validator adalah pada kerangka isi materi yaitu penggunaan kata ganti orang jangan membingungkan dan dibuat sesuai dengan materi ajar. Berdasarkan komentar dan saran validator, prototipe perangkat tes bahasa Arab berbasis kompetensi diperbaiki. Setelah itu, prototipe ini dikonsultasikan kembali kepada pakar sampai perangkat tes bahasa Arab berbasis kompetensi memenuhi kriteria validitas.

Setelah perangkat tes didiskusikan pada para pakar, dan berdasarkan hasil revisi maka selanjutnya diujicobakan pada kelompok siswa. Uji coba kelompok ini terbagi dua, uji coba kelompok kecil dan dilanjutkan dengan uji coba lapangan dalam jumlah yang lebih besar dari sebelumnya. Uji coba kelompok kecil dilakukan pada tiga orang siswa 
yang berbeda tingkat kemampuannya. Hasil dari uji coba pada kelompok kecil ini tidak terlalu banyak mendapatkan revisi. Revisi yang diberikan oleh guru dan siswa cenderung pada perbaikan tata letak gambar serta alokasi waktu.

Setelah perangkat tes diuji cobakan pada kelompok kecil, selanjutnya perangkat tes direvisi. Berdasarkan hasil revisi maka perangkat tes kembali diuji cobakan pada kelompok siswa dalam uji coba terbatas. Jumlah subjek uji coba 30 orang dengan kemampuan siswa yang heterogen. Hasil uji coba memberikan revisi yang tidak banyak dan hampir sama dengan uji coba kelompok kecil.

Setelah perangkat tes direvisi berdasarkan saran validator dan hasil saran dari uji coba pada tiga orang siswa sebagai prototipe I, maka untuk melihat praktikalitas (keterpakaian) perangkat tes, perangkat tes diujicobakan. Uji coba tersebut bertujuan untuk melihat praktikalitas yaitu keterpakaian perangkat tes bahasa Arab untuk siswa Madrasah Aliyah. Ujicoba untuk melihat perangkat tes dilakukan pada kelompok terbatas yaitu pada siswa kelas XI I.A MAN 2 Batusangkar berjumlah 30 orang dengan berbagai ragam tingkat kemampuan. Untuk melihat praktikalitas perangkat tes yang digunakan, diperoleh dari kesan dan pendapat para siswa setelah mengikuti tes melalui wawancara. Secara umum hasil wawancara yang diperoleh dari siswa dan guru menunjukkan bahwa perangkat tes yang digunakan sudah praktis.

Tahap efektifitas dilakukan bersamaan dengan melihat praktikalitas penggunaan perangkat tes yang dikembangkan. Selain itu juga dilihat dari hasil/skor tes, yaitu dari 30 orang siswa, 22 orang mendapat skor $25 \mathrm{~s} / \mathrm{d} 40$ dari 50 jumlah soal yang harus dijawab. Dengan demikian lebih dari separuh siswa mampu menjawab dengan baik dan sesuai dengan yang diharapkan.

\section{PEMBAHASAN}

Perancangan perangkat tes yang telah dikonsultasikan mendapatkan revisi yang tidak terlalu prinsip antara lain tentang pendahuluan, karakter pengetikan, serta kerangka materi/isi. Hal penting yang perlu diperhatikan adalah penulisan petunjuk umum dan petunjuk khusus serta karakteristik penulisan karena dari tulisan yang ada akan mempengaruhi pada kesan pertama siswa terhadap perangkat tes. Dari analisis data mengenai validitas isi dan validitas rancangan/rancangan yang telah dinilai oleh validator menunjukkan bahwa validitas perangkat tes bahasa Arab untuk Madrasah Aliyah yang dikembangkan termasuk dalam kriteria valid, ini menunjukkan bahwa perangkat tes yang dikembangkan dapat mengukur apa yang seharusnya diukur dengan tepat.

Dari pendapat yang diberikan validator tentang perangkat tes bahasa Arab untuk Madrasah Aliyah dikatakan valid dapat dirinci melalui komentar para validator terhadap perangkat tes bahasa Arab sebagai berikut:

a. Perancangan perangkat tes sudah sesuai dengan prinsip pengembangan perangkat tes, menarik dan berdaya guna.

b. Perangkat tes yang dikembangkan sudah bagus dan dapat digunakan untuk pelaksanaan uji coba lapangan/ terbatas jika perangkat tes tersebut telah direvisi.

Hasil penilaian validator dinyatakan sebagai berikut:

a. Pendahuluan soal berupa petunjuk umum dan khusus serta alokasi waktu sudah tepat.

b. Format penulisan: Jenis dan ukuran huruf cocok untuk siswa.

c. Konsep materi yang diberikan sesuai dengan kurikulum dan memungkinkan siswa untuk mudah memahaminya. 
d. Penggunaan bahasa sudah menggunakan kalimat yang jelas dan sederhana, mudah dipahami.

e. Ilustrasi/gambar jelas dan menarik serta dapat mewakili pesan yang ingin disampaikan.

Setelah perangkat tes divalidasi dan hasilnya sudah valid dengan dilakukan revisi, maka tahap selanjutnya dilakukan uji praktikalitas. Dari analisis data berdasarkan hasil wawancara terhadap guru dan siswa, kesan umum siswa menunjukkan bahwa praktikalitas perangkat tes siswa Madrasah Aliyah adalah praktis, sebagaimana uraian berikut:

a. Berdasarkan hasil wawancara dengan siswa tentang kesan terhadap penggunaan perangkat tes secara umum dapat dinyatakan bahwa penggunaan perangkat tes tidak mendapatkan kendala yang berarti, dengan arti lain situasi berjalan dengan normal. Siswa merasa senang mengikuti tes dengan menggunakan perangkat tes yang telah dirancang.

b. Berdasarkan hasil wawancara dengan guru dan siswa terhadap penggunaan perangkat tes secara umum dapat dinyatakan bahwa: penggunaan perangkat tes bahasa Arab praktis dan menarik, karena disajikan dengan disain gambar menarik pada butirbutir soal, disusun berdasarkan urutan kompetensi yang terdapat dalam silabus kurikulum PERMENAG 2008, dan dengan tingkat kesukaran yang berjenjang dari tingkat kesukaran rendah hingga tingkat tinggi.

Untuk menjawab pertanyaan "Bagaimanakah efektifitas dari Perangkat Tes Bahasa Arab Berbasis Kompetensi untuk Madrasah Aliyah?“, maka telah dilakukan deskripsi dan analisis data tentang kesan dan pendapat guru, para siswa dan hasil tes siswa. Berdasarkan hasil analisis data menunjukkan bahwa perangkat tes yang dirancang ini sangat menarik dan setuju jika perangkat tes seperti ini digunakan dalam ujian semester. Efektifitas juga dilihat dari hasil tes yang menunjukkan lebih dari separuh siswa yang ikut tes, mampu menjawab dengan baik dan sesuai dengan yang diharapkan.

\section{PENUTUP}

Dari pembahasan hasil penelitian dapat disimpulkan bahwa Prototipe perangkat tes bahasa Arab berbasis kompetensi untuk siswa Madrasah Aliyah sudah valid menurut para pakar ditinjau dari beberapa aspek yaitu isi perangkat tes dan prinsip serta karakteristik pengembangan perangkat tes. Aspek yang divalidasi yaitu materi, format penulisan, penjabaran materi, penggunaan bahasa dan ilustrasi/gambar.

Selain itu Prototipe perangkat tes bahasa Arab berbasis kompetensi untuk siswa Madrasah Aliyah sudah praktis. Perangkat tes ini mudah digunakan, bermanfaat, menarik. Pada umumnya siswa menyenangi mengikuti tes bahasa Arab dengan menggunakan perangkat tes ini. Pelaksanaan tes berlangsung tanpa kendala yang berarti atau berjalan dalam situasi normal. Adapun efektifitas yang diamati pada pelaksanaan tes ini adalah kesan siswa dan hasil tes siswa. Para siswa merasa perangkat tes ini efektif, yang ditunjukkan dengan hasil tes kebanyakan siswa bernilai diatas rata-rata.

\section{Implikasi}

Penelitian ini telah menghasilkan perangkat tes bahasa Arab untuk Madrasah Aliyah. Pada dasarnya penelitian ini juga dapat memberikan gambaran dan masukan khususnya kepada penyelenggara pendidikan (kepala sekolah, guru bidang studi), dalam meningkatkan kualitas perangkat tes sebagai alat evaluasi. Selain itu dapat membuat pelaksanaan tes pembelajaran bahasa 
Arab menjadi lebih teruji, terukur, menarik, dan efektif serta tidak ditakuti lagi.

Pengembangan perangkat tes bahasa Arab ini dapat dilakukan oleh dosen-dosen dan guru-guru bahasa Arab di satu lembaga pendidikan. Namun yang perlu diperhatikan adalah validitas, praktikalitas serta efektifitas dari perangkat tersebut tidak boleh diabaikan, karena hal-hal tersebut sangat menentukan tingkat kualitas perangkat tes yang dikembangkan.

\section{Saran}

Pengembangan perangkat tes bahasa Arab dalam penelitian ini hendaknya dapat dijadikan sebagai petunjuk bagi guru bahasa Arab untuk membuat butir-butir soal bahasa Arab. Namun

\section{DAFTAR RUJUKAN}

Ainin, M, dkk, Evaluasi dalam Pembelajaran Bahasa Arab, Malang: Misykat, 2006

Arikunto, Suharsimi, Dasar-dasar Evaluasi Pendidikan, Jakarta: Bumi Aksara, 1995

Djiwandono, M. Soenardi, Tes Bahasa dalam Pengajaran, Bandung: ITB, 1996

-------, Tes Bahasa Pegangan bagi Pengajar Bahasa, Jakarta: PT Indeks, 2008

Hidayat, H.D, Menyusun Materi Tes Pilihan Ganda bahasa Arab, Makalah, tidak diterbitkan

Mudhoffir, Tekhnologi Instruksional, Bandung: Remaja Rosdakarya, Cet. V, 1993

Nurgiyantoro, Burhan, Penilaian dalam pengajaran bahasa dan Sastra, perangkat yang dikembangkan dalam penelitian ini dapat dimodifikasi asal saja tidak mengaburkan prinsip dan karakteristik pengembangan perangkat tes.

Hasil penelitian ini menunjukkan bahwa pelaksanaan tes bahassa Arab dengan menggunakan perangkat tes yang dikembangkan dalam penelitian ini dapat meningkatkan daya tarik siswa. Oleh karena itu, dapat dijadikan salah satu alternatif bagi guru.

Karena uji coba perangkat tes ini masih sangat terbatas yaitu 30 orang, sebaiknya guru mengujicobakan pada kelas lain yang paralel atau bagi yang berminat untuk menggunakan sekaligus mengujicobakan perangkat ini di sekolah dengan berbagai kondisi agar kelemahan yang ada dapat dikurangi.

Yogyakarta: BPFE-Yogyakarta, Cet. I, 1987

Purwanto, M. Ngalim, MP, Prinsipprinsip dan teknik Evaluasi Pengajaran, Bandung: PT. Remaja Rosdakarya, 2004

Thoha, M. Chabib, Teknik Evaluasi Pendidikan, Jakarta: PT Raja Grafindo, 1996

Sudijono, Anas, Pengantar Evaluasi Pendidikan, Jakarta: PT Raja Grafindo Persada, 1996

Sudjana, Nana, dkk, Dasar-dasar Penilaian Hasil Belajar, Jakarta: CV Seraya

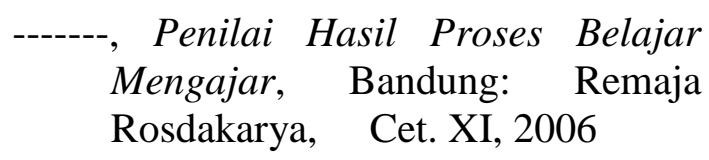

Yunus, Fathi Ali dan M. Abd al-Rauf, al-Marja' fi Ta'lim al-lughah alArabiyah lil Ajanib. 